\title{
Biographical workshop: a place for the secrets of the heart
}

Rosvita Kolb Bernardes rnf.bhz@terra.com.br Brasil

Bernardes, Rosvita Kolb; (2012) "Biographical workshop: a place for the secrets of the heart", p. 357-363. In: Barbosa, Helena; Quental, Joana [Eds]. Proceedings of the 2nd International Conference of Art, Illustration and Visual Culture in Infant and Primary Education. São Paulo: Blucher, 2015. ISSN 2318-695X, ISBN: 978-989-98185-0-7 DOI 10.5151/edupro-aivcipe-67

In this article, I present some reflections on the experience of creating a space for affection in school. In this space, through artistic activity, it became possible to work on losses and nurture secrets, dreams and desires. This place allowed the creation of a sensibility towards each member's individual stories, as well as to a shared memory. The dynamics involved in this proposal expresses a dimension of art teaching that stands directly connected with life, as an action space between objectivity and subjectivity in the work with the students. In this connection, during the classes at the biographical workshop which made up the experience here analyzed, we would combine and compare the participants' stories to the threads of their aesthetic experience, cross referencing African and indigenous cultures with the tradition of women embroiderers, who weave their life stories with yarn and cloth. In the composition of all these elements, we created a space, at school, to accommodate our individualities, the truly hidden treasures of each one of our subjectivities.

\section{The backgrounds of an art project}

Beginning of semester. New classes of students, some of which already known. The class is excited, full of questions and suggestions. Many girls and few boys. Very soon they were telling me they love working with clay... And I asked them: yes, but what did you study in art class last year? What do you think 8, 9, 10-year-old children can learn in art class? (Personal notes, feb. 2005).

This initial conversation and my concerns, as a professor and researcher, as well as those of the children, mark the beginning of this experience I share. Data brought to analysis is related to activities with children between 8 and 10 years old, in an elementary school in the city of Belo Horizonte, during art classes in 2005 . Given this context, this particular moment was especially marked by emotion and sadness (especially for us teachers), for we had just lost a colleague.

As for me, I began the year recognizing life's limitations, facing death as part of the human life cycle. This fact (this awareness) came to me so strongly in my role as a teacher that I began the school year proposing the following work lines to the students: the memory of pain, suffering, loss, and absence.

Could the school be a place for the welcoming of stories and memories of those who attend it? Would it be possible to work the feelings of loss and to encourage secrets, dreams and desires in school? Would it be possible to promote, through artistic activity, ways of seeing and doing that would be sensitive to the stories of each individual? 
The experience on which this analysis is based provides us elements to answer yes to the above questions, and this text is an invitation to think of school as a welcoming environment. In this sense, the school would be a place where we could be connected to our desires, our dreams, anxieties and uncertainties. It would be a place for affection, for memory, and for the sharing of each individual's life stories. A place where we could walk through the halls, sensing the different smells coming from the kitchen and listening to the sounds coming from the yard. A place for running around the yard, exploring the different corners; sitting here or there; joining in circles to talk or have lunch and climbing the trees that make up the educational setting; turning time and space into something that is shared and lived organically.

Living and understanding the school space as a place for our affective memory means to recognize and revive the school's spots in a way such as to recover meaning imprinted on them and shared amongst all those who once lived or still live in these spaces. But at the time I formulated the proposal for art classes - of pulling threads and weaving the life stories brought by the students - I was still not aware of this possibility, and even less of the importance and vitality that these spaces could have on the history and the memory of students and teachers.

What is living the present? What is the past? In the everyday living at schools it is common to look at the past as a preparation for the future. However, in his analysis of history, Benjamin (1994) speaks of a living past, which can be redone and in which the subject has a key role. The past can be remade if connected to the present. However, how can you promote this in school, if students do not arise as living and active subjects in their daily experience, being deprived of telling their own stories? The massification process deprives us from the art of storytelling and diminishes our experience. In other words, serially molded, people lose their history, and are no longer the actors of their lives.

Kramer (1993) teaches us that proactive students and teachers have the ability to interact and inter-relate as they tell, write or speak about themselves and the life they live, rebuilding trails, creating new paths as they recount their stories, creating a new past from this mutual experience in the present. For if students and teachers tell stories and have meaningful experiences, couldn't they give a new significance to knowledge? One that creates itself through a sense of affection, by the cultural dimension of children and adults who live in school?

Souza (2006) speaks of the importance of studying life stories as tools to understanding how school knowledge is produced. People learn from their own stories, and the act of telling these stories creates a space to talk, think and feel about themselves and others.

Gradually, my concern to ensure time in school for the narratives that students brought me began to shape as a project, making way for a methodological approach in which the stories that were lived and shared were not always presented through writing (the most common procedure in school...). Other methods of telling were proposed and incited as ways of sharing the stories they produced, presented in the form of drawings, diaries, pictures of objects; or yet, significantly configured as small boxes containing objects that were collected and gathered together, giving their memories and stories new meanings. In this last case, extremely symbolic meanings emerge: these boxes, "embedded memories", would come as "treasure boxes" (Schatzkästlein in German), according to Hebel (cited in BENJAMIN, 1994). And could there be anything more precious than the living life?

In this direction, in my practice as a teacher I began understanding that art classes can provide students the opportunity to recount their stories, rebuild their past and form their identity through various doings, in which the word combines itself with other materialities. In this approach, the activities in art classes have been rethought, seeking to dialogue with the local culture and other Brazilian cultural events.

To nurture and instigate the children, I brought to class a book entitled "Guilherme Augusto Fernandes Araújo" (FOX, 1995), which tells the story of a boy who helps an old lady, a resident of a nursing home close to his house who was losing her memory, to recall her life through different objects full of personal meanings.

Reading this story helped in the exercise of remembering and, gradually, the students started bringing their memories, at first in writings: "I miss when I was younger" (9-year-old child); "To me, memory is the past, present and future, time, hours and days. The pictures I brought are of 
2nd International Conference

Art, Illustration and Visual Culture

in Infant and Primary Education $2^{\circ}$ Congreso Internacional

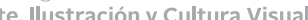
en Educación Infantil y Primaria ressolnternacional

de Arte, Ilustração e Cultura Visual

na Educação Infantil e Primária
The many threads of the woven story: embroidery, amulets, rituals friends, who remind me of the time of the people we like, of friends of the past, people who have not yet arrived, present friends and new ones yet to come" (10-year-old child); "But there are so many people I keep in my heart, even if forgotten, because everything was lived, felt, everything thought, everything said, and I enjoyed being multiple selves" (10-year-old child).

From this point we followed on, attaching our stories to the threads of the aesthetic experience, crossing our references with the African and indigenous cultures and with the women embroidery tradition from Minas Gerais, who weave their life stories with threads and fabrics. It was explicitly visible how this experience involving memory, desires and secrets became more intense when we had contact with the Quarup legend of the Kamaiurá Indians (Xingu), with the making of talismans of the African tradition and with the embroidery of the "Dumont Family" and the "Mariquinhas". Such situations and planned activities, constituting the core of our now developed project, led us to different universes, expanding the students' repertory and provoking not only the mind, but the emotion as well, strongly connecting these two dimensions in our new doings.

\section{Pulling the threads: embroidery and embroiderers}

When visiting the "Mariquinhas" embroidery exhibit with the students in an art gallery in Belo Horizonte, we were delighted and also very impacted. The "Mariquinhas" embroiderers weave their stories of suffering and struggle for survival. They live on the suburbs of Belo Horizonte, from where their embroidered, stitched and narrated cloths come, bringing memories of difficulties, of moments of joy and sadness.

At times, the children were confused and thought the embroideries were not real. They thought the woven stories were imaginary and, on the way back to school, commented that it was too much suffering, too much pain on one piece of cloth only, and for only one person to bear...

With the Dumont Family, who lives in the north of Minas, in the city of Pirapora, we learned to dialogue with the threads, fabrics and embroideries that carry great plastic and visual strength and sensitivity, having delicacy as a big differential. They constitute memories filled with living life poetry, and other times with reference in literature.

\section{Amulets: giving shape and building a place for pain}

On a visit to the exhibition "Mostra do Descobrimento Brasil + 500" "The Discovery of Brazil +500") in São Paulo, my attention was driven to artist Rosana Paulino's work, "Parede de Memória" ("Memory Wall"). It was composed of 850 small photos from her family album. They were worn-out pictures, in a faded tone, which brought us her story. It was as if she articulated the past and the present as she spoke of her life, related to her historical and social conditions. From the exhibition catalog, and Carlos Drummond de Andrade's poem "Carrego comigo" ("I carry with me"), came the inspiration for the proposition of making amulets with the children. Symbols of good fortune and protection, the amulets are small sewn pads, containing an aromatic herb, and a note with the desires, dreams and that which we bring in our luggage throughout life. As we had a closer look at this artist's work on the catalog I took to class, the children and I observed some details: there were photos of people printed on the small sewn cushions. As we had more contact and more information, we discovered that the artist is an African-Brazilian descendant, which possibly gave support to her work with the amulets. Maybe, maybe not, but the fact is that, looking at her work, we decided to follow the path shown therein: for the time being we would bring the significance of the amulets to the artistic work we would carry, we would make amulets, because we needed to give form to our feelings, to the visible pain that took over us at the beginning of the year, that we could no longer bear inside.

The poetry of Carlos Drummond came as a gift! It allowed us to plunge within the strength and depth of the words, of what is said and what is not. Of what is understood or what is not. When reading the poetry, the poet's verses made sense to the children.

For decades, for hundreds of years, I carry with me the small package. Does it hold a couple of letters? Will there be a flower? A picture? Perhaps a scarf? Where I found it, I cannot recall. Was 
it a gift or was it stolen? Did the angels come down bringing it in their hands? Was it floating in the river, or was it drifting in the air? I dare not open it. What it contains, if anything, l'll never know. How could I try this gesture? The package is so cold and yet so warm. It burns in the hands, it's sweet to my touch. It fascinates and makes me sad at once. To keep a secret within and to yourself, not wanting to know it or wanting to know too much. Keeping a secret from your own eyes, underneath your sleep, behind the memory (ANDRADE, 2001, p. 29-32).

After reading the poem, I gave each child a piece of paper where they could, individually, in a very free and spontaneous way, according to their own possibilities, write about themselves, about their losses, secrets, dreams and desires...

Some chose to lie down on the floor to write. Others hid under the table, behind the curtains, and others sat in the usual place... Suddenly, someone came up with a question: "Will someone read what we write? Secrets are secrets, and if I read them to someone, they would be no longer secrets...". I understood that this child was claiming a special place for this writing, a space for intimacy, where he could write to himself, not to someone else. At school we learn that everything we write is directed to someone. This child's speech expressed what I had been thinking, reinforcing that what we were experiencing at that time called for a special place.

After writing the notes, which were stored in supposedly safe places for them, as in their pants' pocket or in a pencil case, we went to the making of the amulets. This was the moment to look at the fabrics, at the pieces of cloth, at the colors. There was a little of everything amongst the available material. The fabrics were smooth, silky, thin and velvety. They came in bunches, brought by the children from their homes. Each one chose their piece. In their piece of cloth, their color. The choices were the most diverse. Some preferred the lighter colors, others the darker. Yet some children were in doubt because they wanted to relate the color to the note writing... At times like this, facing the choice of the materials to be used, is when the aesthetic perception is manifested; in this case, when confronting the choice between the different fabrics, their textures, colors, sizes. The children talked about their perceptions in the contact with the material, such as: "I liked this cloth so much... it is so soft and the colors are so light. It's beautiful."

After the choosing of fabrics comes a new step: sewing the amulet and filling it up with the note. We worked with thick blunt needles and skeins of colored threads. The sewing took a couple of lessons. There were many threads, many knots, many out of place stitches they wanted to handle by themselves and include in their sewing. All this lasted longer than the expected. There were times I thought this activity would never end! Some students, for instance, couldn't contain their anxiety and ended up writing various notes, and sewing various amulets.

Some notes were sewn on the cushions, on the amulets. Other ones were just stored in the memory, in each one's life story. Some children could not contain themselves and revealed their secrets. Other children made confessions: "I'll only open my amulet when I get married...".

By observing the children, their choices and what they made, I could identify signs that showed they were really involved, each one with their sewing, with their story. This reminded me of artist Fayga Ostrower's words (1987, p. 22):

When people actively participate in the making of forms, seeing them emerge in their hands, not only does this create an affective scenario immediately fulfilled with emotional associations, but also the concrete example is always more eloquent than abstract explanations.

It was an aesthetic activity that provided a space for talking about themselves, in which the pulling of threads, the choosing of fabrics, the privileged colors, the writing of notes all spoke about each one of them. A place for their welcoming, open to the listening of the song that sings in each one of their hearts. It was certainly a special moment for the children, as well as for me.

\section{Birth, death, rebirth}

Another outgrow of this same activity was the contact with the "Quarup" legend, part of the Kamaiurá Indians' rituals (Xingu, Brazil), in which the cycle of birth-death-rebirth is celebrated. We watched a video about the feast of the dead, in which logs of "Quarup" wood were taken to the village to be painted and adorned with feathers, beads and cotton thread. At this activity 
2nd International Conference Art, lllustration and Visual Culture in Infant and Primary Education $2^{\circ}$ Congreso Internacional

Arte, Ilustración y Cultura Visual en Educación Infantil y Primaria $\circ$ Congresso Internacional

de Arte, llustração e Cultura Visual

na Educação Infantil e Primária

I had the partnership and involvement of another school teacher, who also worked with this group of students. After watching the video, we sat in a circle in the classroom floor and read the story about this legend aloud to the children, from the book Xingu: the Indians, their myths (VILLAS BOAS \& VILLAS BOAS, 1970).

At the beginning of the reading, the children found this religious ritual to be strange, and challenged us with questions like: "How can it be that they don't cry when someone dies? Do the dead, to the Indians, really not die? Do they come back?". Another boy then contributed to this idea, saying that when his grandfather died, he didn't cry, because he knows that his grandfather is "somewhere out there..." "In heaven?", someone asked. Another child, who had seen a television program on the Day of the Dead in Mexico, brought the information that over there they sing and party at the cemetery: "I think it's an honoring that people do to dead people".

At that moment, we focused back on the video and the on the legend, emphasizing the importance of the various rituals that exist in different cultures and how each social group creates its own rituals. This, somehow, began to make sense to some children in the moment they were able to look at themselves.

After these interactions, they initiated the creative activity, by making a drawing, a self-portrait. In the back of the drawing, they listed their losses, their longings, the missing of people and of things. When this was finished, they colored the background of the picture by using crayons, leaving the self-portrait drawn in pencil.

The video and the reading of the legend were elements that helped us in conducing our aesthetic sense for the drawings and writings produced by the students. Having the indigenous ritual as a reference, we took advantage of a freshly cut tree stump at the school entrance, using it as an artistic instrument. Looking at this ritual, we had the idea to paint the tree trunk, put cotton yarn over it, hang the pictures/self-portraits on it, with the writings of our losses, sorrows and absences. Once everyone was ready with their drawings and writings, we created our own ritual.

We sat in a circle and in the middle, at the midpoint of the circle, was the "Quarup" made by the children. We agreed that each child, one at a time, would have the opportunity to go to the middle of the circle, and, right next to the "Quarup", get to read what they had written and then attach their picture to the trunk afterwards.

Twenty children participated in this activity, and were able to stay in complete silence, waiting for their turn to read, in an impressive atmosphere of respect for the others. As they read and spoke, they created a shared feeling of intimacy, of acquaintanceship, of exchange, along with the possibility of self-encountering, all resulting from the "exploration of colors, lights and shadows, the facing of anxieties and fears, the confronting of our ghosts, the discovery of new pleasures, the creation of new processes to invent dreams" (ALBANO, 1991, p. 161).

This seemed to be exactly what the children wanted: to invent new dreams, to discover new paths, new processes for their losses, sorrows and anxieties. In the writings that were on the back of the drawings, they speak of the little fish that had died, of how they still miss their baby bottle, of the untold death of an uncle, of the friend who moved to another city, of how a teacher was missed, of the joy of getting a dog, of a brother to be born, of the grandfather who died and who taught him to love. Where would these feelings and senses be, if there hadn't been a proposal for conducing them, for giving them shape through a variety of expressions?

Once creating an environment in school to accommodate each one's subjectivities, we also created a line of work that allowed the students to recognize themselves as belonging to a particular social group. It also helped them realize that pain and suffering, sometimes present as a theme in the work of some artists, is part of life, including theirs, and ours.

I think that working with education is not a solitary mission, but a venture that involves the other. And involving the other, as Formenti (2008) tells us, means caring and being concerned for them. And what is the dimension of this care and concern when dealing with the memories, objects, dreams, desires and complaints the students bring to class? Is there sensitive listening to them, is there a place to accommodate what they bring? 
$2^{\text {nd }}$ International Conference Art, Illustration and Visual Culture in Infant and Primary Education congresso Internacional de Arte, llustração e Cultura Visual na Educação Infantil e Primária

This experience showed me how important it is to listen and to be listened to at school. Talking about ourselves establishes connections for both the one who speaks as for the listener. Gambini (2001) illuminated me when he pointed out the huge gain this kind of activity can have for us educators. According to him, the more we can learn about those who stand before us, the more able we, as educators, are to place ourselves somewhere else. An activity like this allows us to observe the student from another perspective: the place where the imaginary, the subjectivity, and the symbolic lies. After all, the author says, the unconscious creates the willingness to learn, opening doors to life experiences.

To propose working with creation through the perspective of different cultures, enables us to establish a method of art teaching that articulates itself with the diversity we find in our reality, allowing room for the different experiences and stories to come to school, to invade our classrooms and take over us, creating, thus, another dimension and disposition for learning.

Having memory be a trigger of an artistic/affective/aesthetic process also reaffirms the need to assure that emotional experiences - sorrows, loves, losses, absences, desires - have a place in the thinking and producing of art at school. In the experience analyzed here, the conversations - open space for dialogue and for the narratives of the lived experiences in which we spoke and wrote about ourselves - and the contact with different cultures were the elements that allowed us to create such precious and differentiated pieces as the amulets, covered with symbols. Creations that, beyond simple art making, carried and revealed "secrets of the heart" - filled with our desires and dreams, that were written and sewn on cloth, using the folded, then stored and at last affixed little notes.

Thus, we created in school a receptive place for individuality, for the welcoming of each person's subjectivity. We exercised both seeing and doing, integrating thought and feeling, sensation and intuition, claiming art as a space for this totality, and the space of art teaching as a place of many secrets...

\section{Referências}

ALBANO, A.A. O ateliê de arte na escola:espaço de criação e reflexão. In: PACHECO, E. (Org.). Comunicação, educação e arte na cultura infanto-juvenil.São Paulo: Loyola, 1991. p. 159-168.

ANDRADE, C.D. Carrego comigo. In: ANDRADE, C.D. A rosa do povo.23. ed. Rio de Janeiro: Record, 2001. p. 29-32.

BENJAMIN, W. Magia e técnica, arte e política: ensaios sobre literatura e história da cultura. São Paulo: Brasiliense, 1994. (Obras escolhidas, v. 1)

FORMENTI, L. A escrita autobiográfica e zelo: um olhar composicional. In: PASSEGGI, M.C. (Org.). Tendências da pesquisa (auto)biográfica. São Paulo: Paulus; Natal: EDUFRN, 2008. p. 51-71.

FOX, M. Guilherme Augusto Araújo Fernandes. São Paulo: Brinque-Book, 1995.

GALZERANI, M.C. Imagens entrecruzadas de infâncias e de produção de conhecimento histórico em Walter Benjamin.São Paulo: Cortez, 2002.

GAMBINI, R. Sonhos na escola. In: SCOZ, B. (Org.). (Por) uma educação com alma. Petrópolis: Vozes, 2001. p. 102-157.

KRAMER, S. Por entre as pedras: arma e sonho na escola. São Paulo: Ática, 1993.

OSTROWER, F. Universos da arte. Rio de Janeiro: Campus, 1987.

SOUZA, E.C. O conhecimento de si: estágio e narrativas de formação de professores. Rio de Janeiro: DP\&A; Salvador: UNEB, 2006.

VILLAS BÔAS, O.; VILLAS BÔAS, C. Xingu: os índios, seus mitos. São Paulo: Círculo do Livro, 1970. 
$2^{\text {nd }}$ International Conference

Art, Illustration and Visual Culture in Infant and Primary Education
- Congreso Internaciona

y Cultura Visual en Educación Infantil y Primaria de Arte, llustração e Cultura Visual na Educação Infantil e Primária 